\title{
Cocoplum (Chrysobalanus icaco L.) Identification and
} Uses $^{1}$

\author{
Stephen H. Brown and Marc S. Frank ${ }^{2}$
}

Family: Chrysobalanaceae (cocoplum family)

Common Names: cocoplum; fat pork; icaco

Origin: central and south Florida; West Indies; Mexico; Central America; northern South America; West Africa

USDA Zone: $10 \mathrm{~A}-12 \mathrm{~B}\left(32^{\circ} \mathrm{F}\right.$ minimum $)$

Plant Type: shrub; small tree

Growth Rate: moderate, coastal ecotype; fast, inland ecotype

Typical Height: 6-feet coastal ecotype; 20-feet inland ecotype

Leaf Persistence: evergreen

Leaf Type: simple, entire

Flower Color: white

Fruit Color: purple; white, sometimes blushed pink

Light Requirements: full sun; moderate to light shade

Soil Requirements: acidic to alkaline; clay to sandy; seasonally saturated to seasonally dry

Drought Tolerance: medium
Salt Tolerance: high

Wind Tolerance: high

Nutritional Requirements: low

Propagation: seeds; cuttings; air layering

UF/IFAS Assessment: native

Human Hazards: none

Occasional Problems: lobate lac scale; weevils; algal leaf spots; Botryosphaeria canker

Uses: hedge; specimen; groundcover; roadway; small tree; edible fruits

Table 1. Nomenclature of Chrysobalanus icaco

\begin{tabular}{|l|l|}
\hline Kingdom & Plantae \\
\hline Phylum & Tracheophyta \\
\hline Order & Malpighiales \\
\hline Family & Chrysobalanaceae \\
\hline Spenus & Chrysobalanus \\
\hline Subspecies & $\begin{array}{l}\text { Chrysobalanus icaco L. } \\
\text { C. icaco L. subsp. icaco native to tropical America } \\
\text { and coastal West Africa and C. icaco L. subsp. } \\
\text { atacorensis (A. Chev.) F. White, native to West and } \\
\text { Central Africa }\end{array}$ \\
\hline Cultivars & 'Horizontal,',Red Tip,,'Green Tip' \\
\hline
\end{tabular}

1. This document is ENH1289, one of a series of the Environmental Horticulture Department, UF/IFAS Extension. Original publication date March 2018. Visit the EDIS website at http://edis.ifas.ufl.edu.

2. Stephen H. Brown, horticulture agent, UF/IFAS Extension Lee County; and Marc S. Frank, Extension botanist, UF/IFAS Plant Identification and Information Service, University of Florida Herbarium; UF/IFAS Extension, Gainesville, FL 32611.

The Institute of Food and Agricultural Sciences (IFAS) is an Equal Opportunity Institution authorized to provide research, educational information and other services

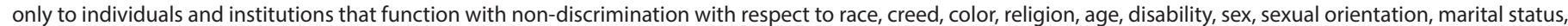

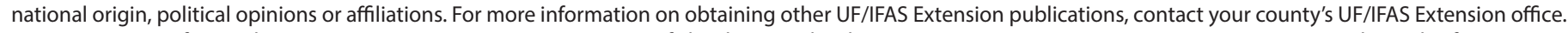
U.S. Department of Agriculture, UF/IFAS Extension Service, University of Florida, IFAS, Florida A \& M University Cooperative Extension Program, and Boards of County Commissioners Cooperating. Nick T. Place, dean for UF/IFAS Extension. 


\section{Global Distribution}

Cocoplum is native to central and south Florida, the West Indies, Mexico, Central America, South America, and West and Central Africa. It is cultivated elsewhere and has become naturalized in the Seychelles, Vietnam, Singapore, French Polynesia, and Fiji.

\section{Florida Distribution}

Cocoplum (Chrysobalanus icaco L. subsp. icaco) is one of two native Florida plants in the Chrysobalanaceae family. The other is gopher apple, Geobalanus oblongifolius (Michx.) Small. Cocoplum is native to coastal habitats from Pasco and Brevard counties southward, but is now cultivated in both inland and coastal parts of the peninsula in USDA Hardiness zones 9B and higher. In its native range, it is found in a variety of habitats, including coastal strands and dunes, scrubs, pinelands, hammock edges, riverbanks, canal banks, and the margins of cypress swamps and freshwater marshes. In some south Florida locations, remnants of former populations may be found on undeveloped urban lots.

\section{Ecotypes}

Plant ecotypes or forms are populations that survive in isolation and develop minor but distinct characteristics in response to local environmental conditions, such as differences in growth habit, leaf shape or color, and flower and fruit size or color. There are two ecotypes of cocoplum as distinguished by their growth habits.

The coastal form is highly salt tolerant and has a moderate growth rate. It forms densely foliated mounds from ground to top, which are typically wider than high and usually not more than six feet tall. Spreading, low-growing plants are likely to form dense thickets.

A second form occurs mostly inland away from the coasts. Plants are fast, upright growers usually becoming 15 to 25 or more feet tall with an equivalent or wider width. They are either single or multi-trunked plants. The trunks of older single-trunked specimens are usually 5 to 7 inches in diameter. Branching may not occur until several feet above the ground, at which point they become densely foliated. Older multi-trunked plants also have dense foliage that touches the ground, giving them a symmetrical rounded or dome-shape appearance.

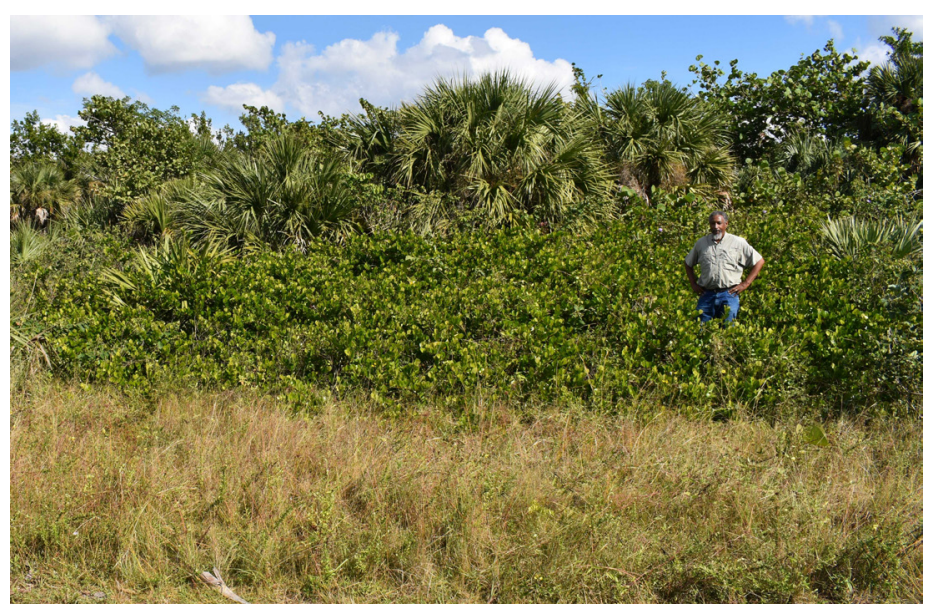

Figure 1. A portion of a single, fourteen-year-old, unpruned coastal form of mounding cocoplum.

Credits: Jeff Holbrook

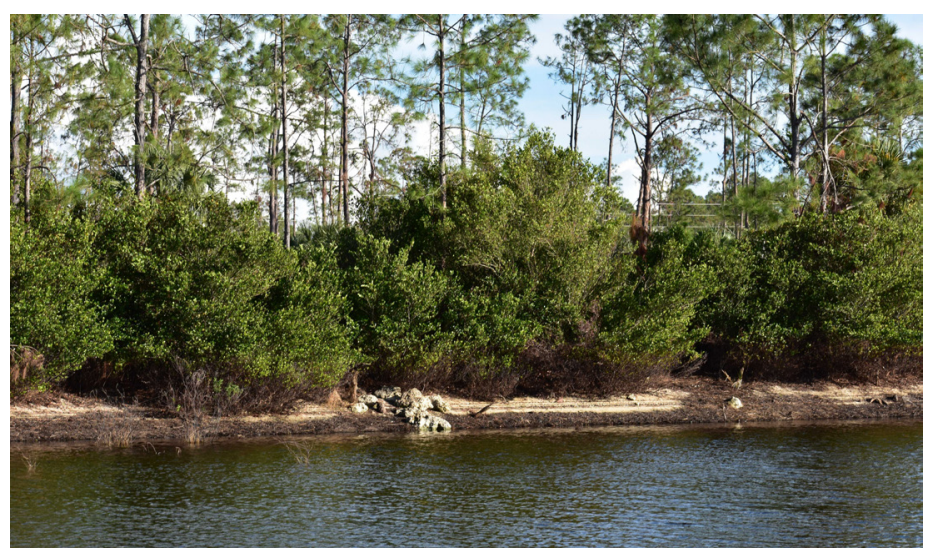

Figure 2. Naturally occurring plants of inland upright form of cocoplum.

Credits: Stephen H. Brown, UF/IFAS

\section{Cultivars}

A cultivar is a plant variety purposefully bred or selected by humans for its distinctive characteristics. They may not produce true to type when grown from seeds. Thus, cultivars are mostly produced clonally from stem cuttings or tissue culture. This method of plant propagation guarantees plants will have the same characteristics as the parent plant.

\section{'Horizontal'}

'Horizontal' is the cultivar synonymous with the coastal form of cocoplum. There are no other coastal ecotypes known. When grown in close proximity to the inland forms, hybridization occurs. As its name suggests, 'Horizontal' has a sprawling growth habit. For this reason, it is used mostly as a groundcover, but also makes an excellent hedge. Its new leaves are light-green to yellow-green, and mature fruit are predominantly white, white blushed with pink, or (less often) purple. This cultivar was once called "Hobe Sound cocoplum" because it was found at that location in coastal Martin County. It has also been called "dwarf 
cocoplum," which is misleading because it is not a dwarf selection. It typically does not exceed a height of six feet.

\section{'Red Tip, 'Green Tip'}

'Red Tip' is a cultivar of the inland form of cocoplum. The color of the new leaf growth is burgundy-red, becoming yellowish-green and then dark-green. The mature fruit color is usually purple. This cultivar has become the dominant cocoplum hedge of south Florida. There is also reference to a 'Green Tip' cultivar. This may simply be a way of describing plants of the inland ecotype without the burgundy-red new growth. They have light-green new leaves that become dark-green. Mature fruit color is predominantly white and often blushed with pink. Both cultivars are capable of growing up to 25 feet or more in height.

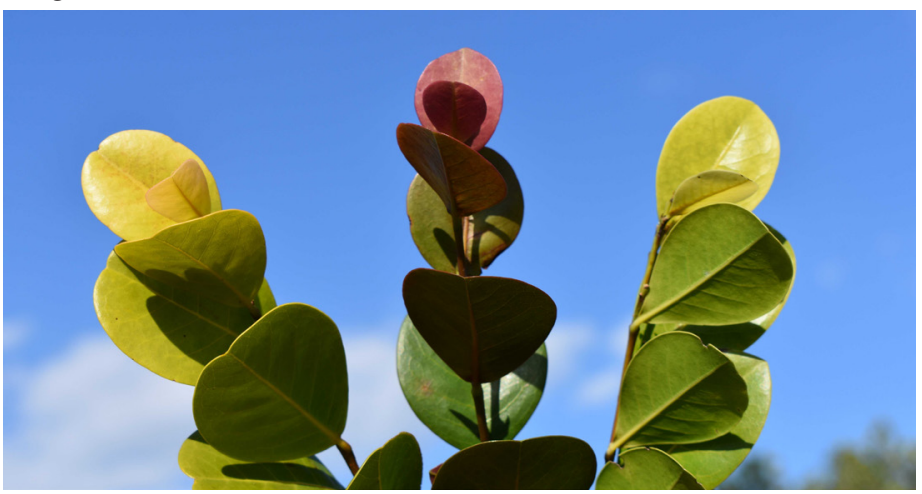

Figure 3. Left to right: New growths of 'Horizontal,',Red Tip,' and 'Green Tip' cultivars.

Credits: Stephen H. Brown, UF/IFAS

\section{Shoots}

New shoots of all cultivars are green and smooth and may be produced year-round. As they age, they become brown, hardened, and stiff, developing many conspicuous raised, elliptic, white, or tan lenticels (pores for gas exchange). Hardened twigs retain their leaves and bear axillary and terminal flowers and fruit, which are sometimes obscured by the dense foliage.

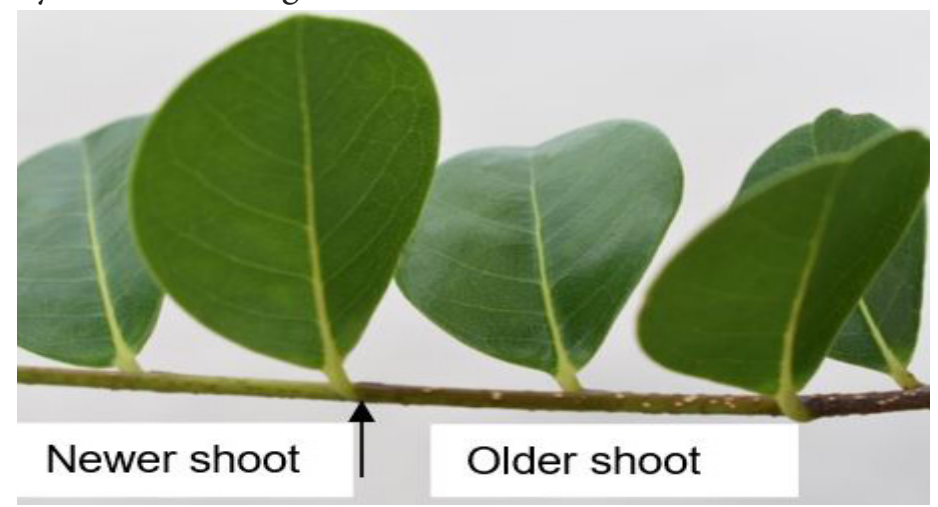

Figure 4. Delineation between newest and oldest shoots. Credits: Stephen H. Brown, UF/IFAS

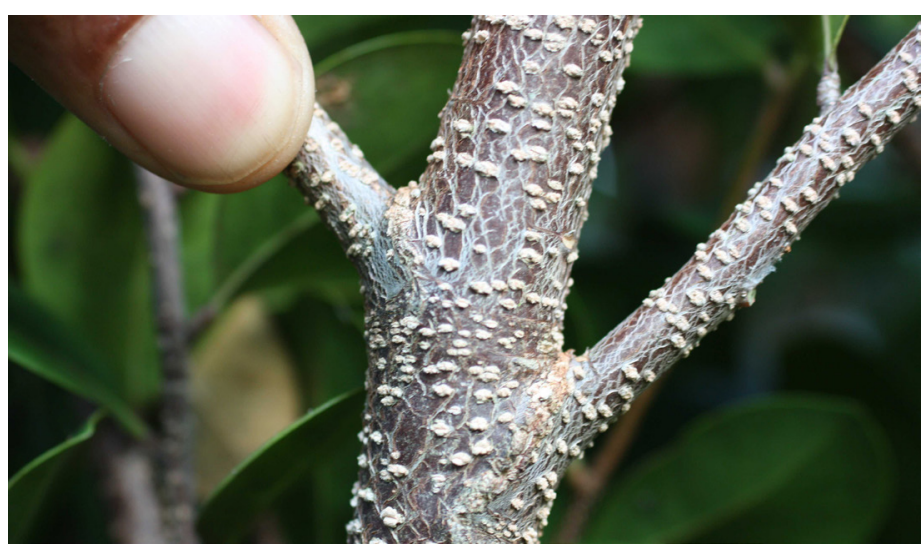

Figure 5. Conspicuous, raised, elliptic, lenticels. Credits: Stephen H. Brown, UF/IFAS

\section{Leaves}

Cocoplum leaves are alternate, simple, and entire. They point upwards, forming a $\mathrm{V}$-shaped angle along the upper side of the stem. The blades are mostly 1.5 to 3.50 inches long, broadly elliptic, obovate (wider above the middle) or nearly round, and attached to a short petiole approximately 0.125 inches long. The tips may be slightly pointed, rounded, or notched. The base usually tapers to a point or is obtuse or rounded. The margins are thinly and tightly revolute (rolled under), which can be felt by moving a finger across the lower leaf margins. New leaves are thinner-textured, yellowish-green or often red-tinged. With age, they become leathery, smooth, shiny, and darkgreen on the upper surface and a paler, matte green below. Midveins are lighter colored and prominent, except toward the distal (uppermost) portion of the blades.

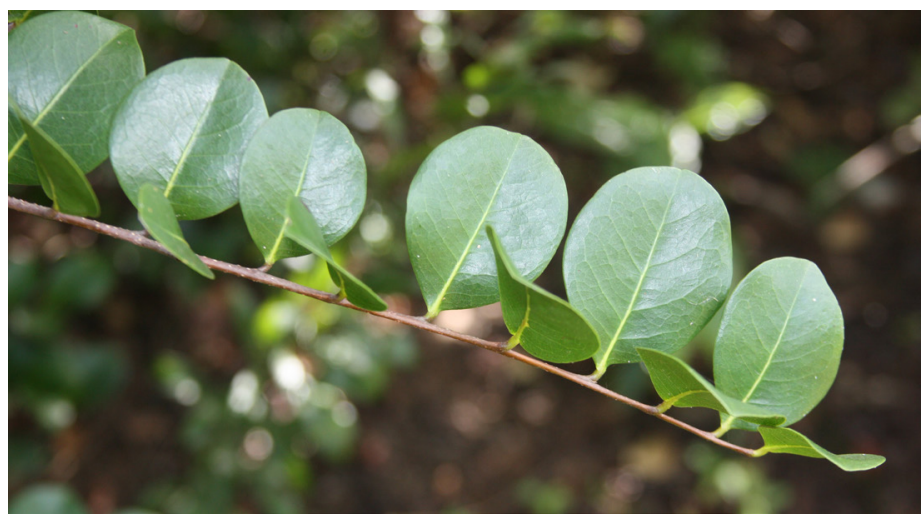

Figure 6. Upright, alternately arranged leaves forming a V-shaped angle.

Credits: Stephen H. Brown, UF/IFAS 


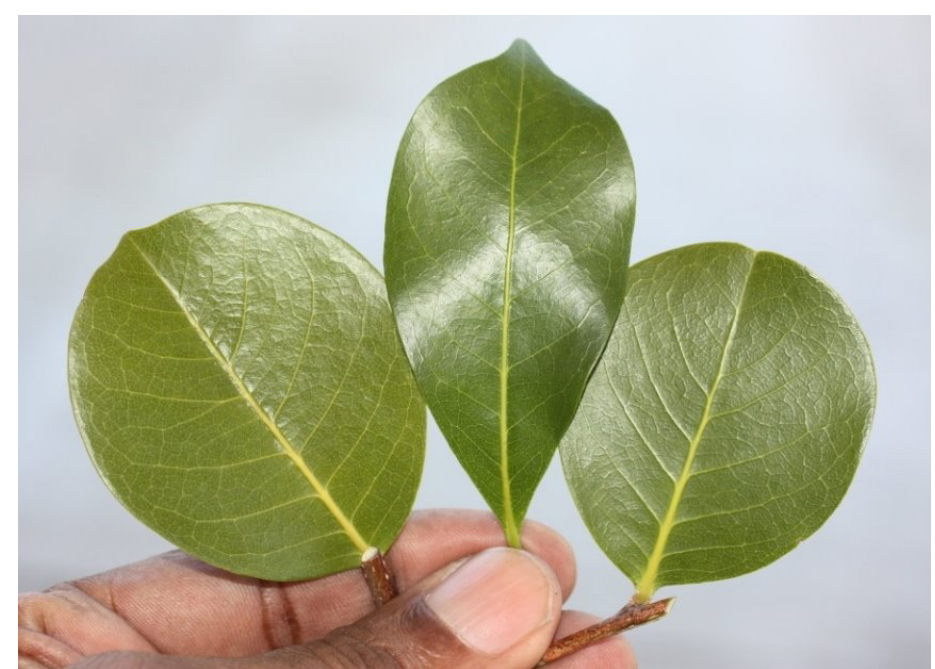

Figure 7. Leaf blades are broadly elliptic, obovate (center), or nearly round. Apices are rounded, abruptly pointed, or notched.

Credits: Stephen H. Brown, UF/IFAS

\section{Flowers}

Flowering is mostly from January to August, but the main flowering period is usually late spring. The flowers occur in rather inconspicuous, short, axillary, and terminal clusters called cymules (few-flowered, poorly branched inflorescences in which the central flower matures first). Each flower is perfect (with both male and female sexual organs), and measures about 0.25 inch long. The five distinct (unfused), spreading, pale greenish-to-yellowish sepals and five narrow, white petals are borne atop a conical receptacle (flower base or axis). The stamens vary in number from 12 to 25 , and are irregularly fused into an erect, densely hairy tube in the center of the flower. The ovary is also shaggy and hairy, but the hairs are lost as the fruit develops.

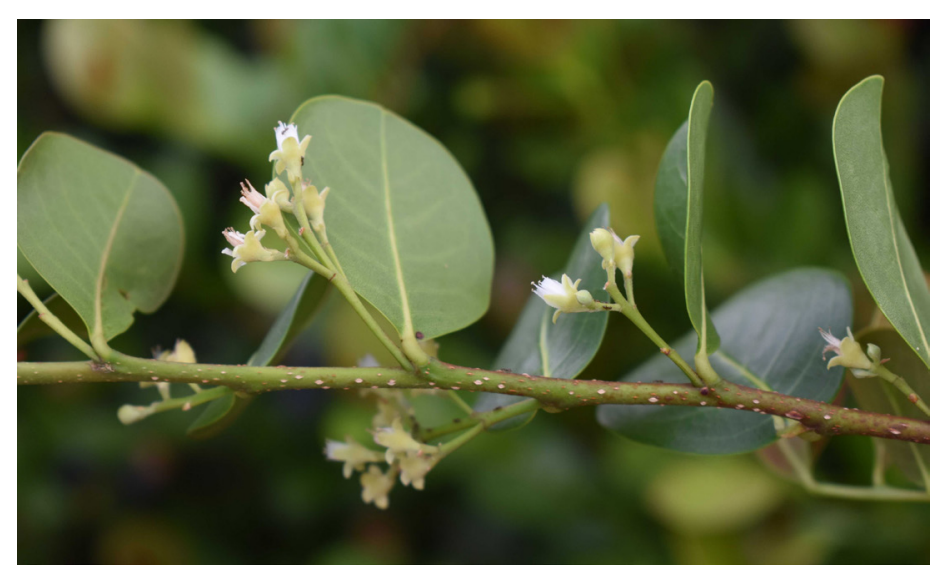

Figure 8. Axillary cymules hidden amongst the foliage. Credits: Stephen H. Brown, UF/IFAS

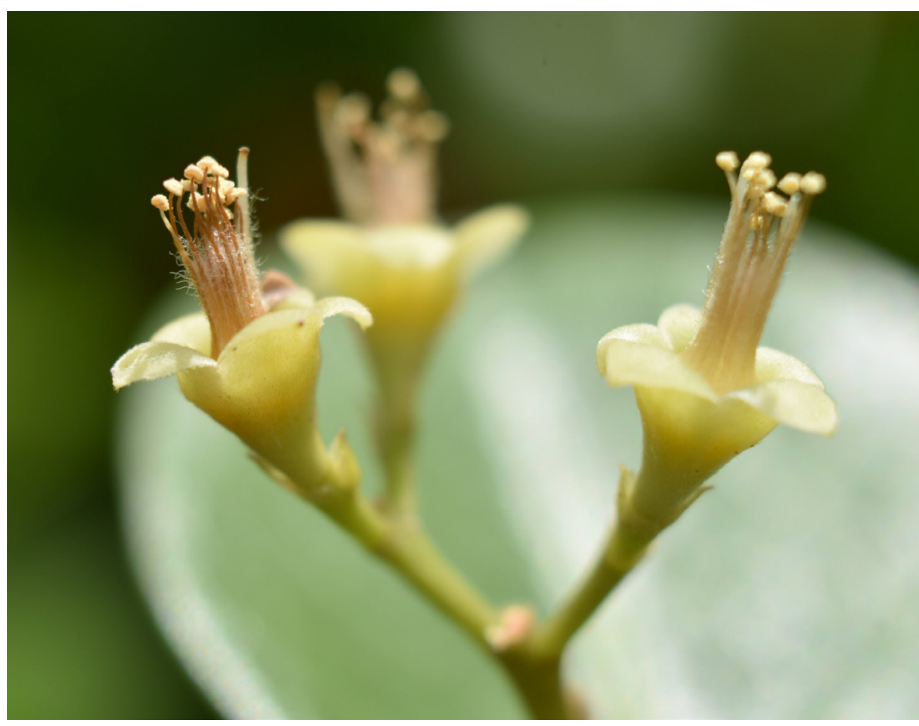

Figure 9. Flowers in cymule. The spreading, pale-yellowish structures are the sepals (petals have already apparently been shed).

Credits: Stephen H. Brown, UF/IFAS

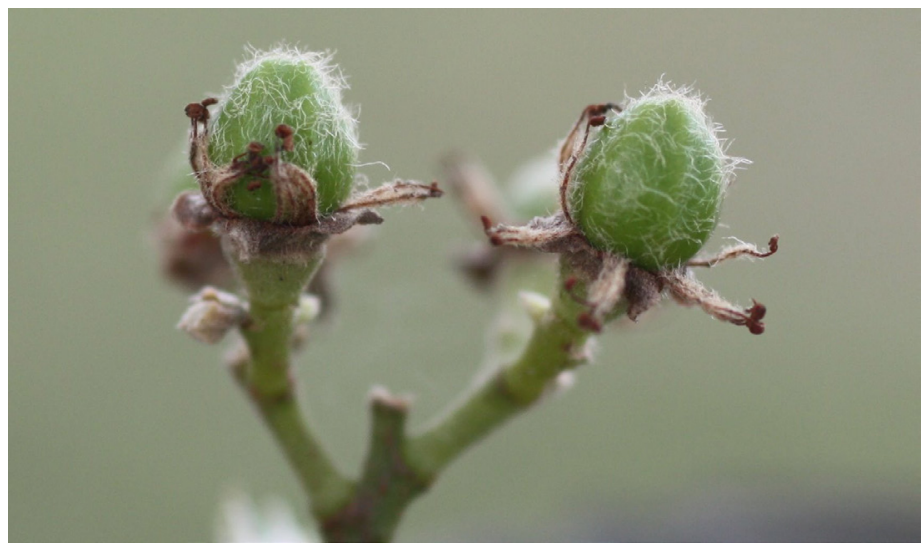

Figure 10. Shaggy, hairy ovaries that will become mature fruit. Credits: Stephen H. Brown, UF/IFAS

\section{Fruits}

Fruiting is abundant from late spring through summer. Immature and mature fruit are often found on the same fruiting cluster. Immature fruit are green and become purple, white, or white-blushed pink when mature. They do not ripen when picked prematurely. Mature fruit easily detach from the stem and fall below the plant or are removed by people or wildlife. They are soft and edible, slightly sweet and pleasant tasting, while others are somewhat insipid.

Fruits are thin-skin drupes on short pedicels. 'Horizontal' fruit is white, white with pink blush, or (less often) purple. They are round, typically up to 1.5 inches in diameter. 'Red Tip' has oblong, purple fruit. 'Green Tip' has white (or occasionally purple) oblong or rounded fruit. Both inland cultivars have smaller drupes than their coastal counterpart, mostly 0.75 inches in diameter. The white pulp surrounds a single pit with a hard endocarp, bearing 4 to 8 longitudinal ribs. 


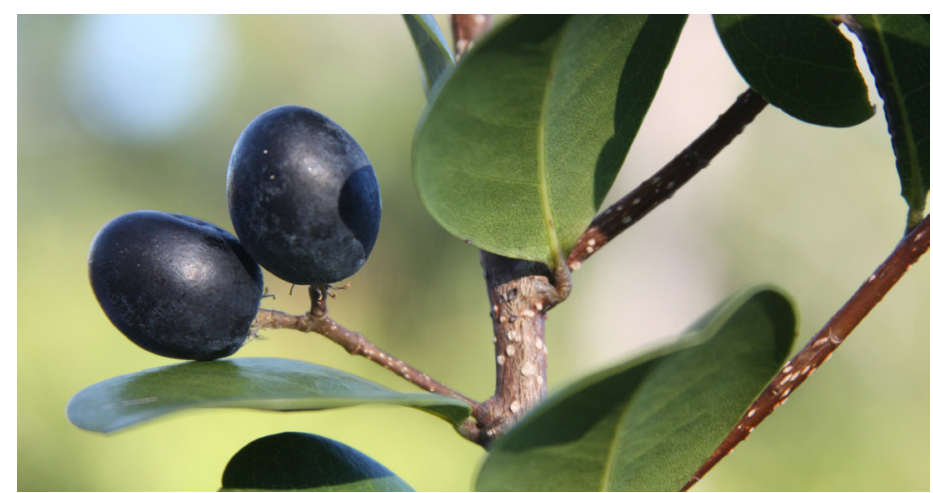

Figure 11. Oblong purple fruits on the inland ecotype of cocoplum. Credits: Stephen H. Brown, UF/IFAS

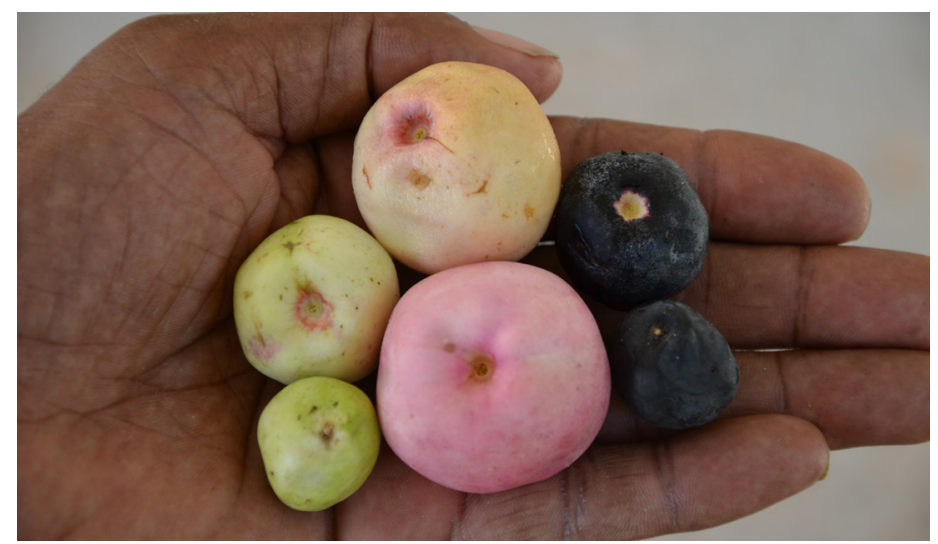

Figure 12. Typically appearing fruits. Left: 'Green Tip,' Center: 'Horizontal,' Right top: 'Green Tip,' Right bottom: 'Red Tip'. Credits: Stephen H. Brown, UF/IFAS

\section{Best Ways to Identify Cocoplum}

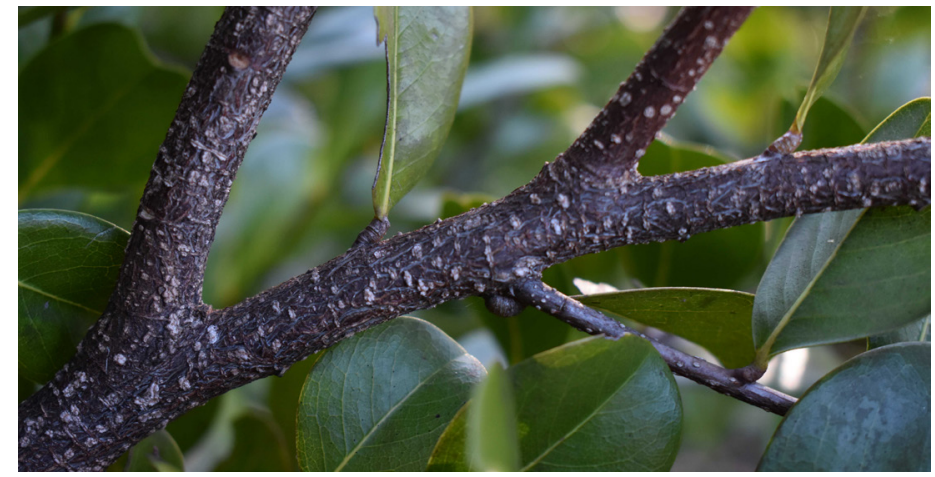

Figure 13. Mature branch with prominent, lighter-colored lenticels. Credits: Stephen H. Brown, UF/IFAS

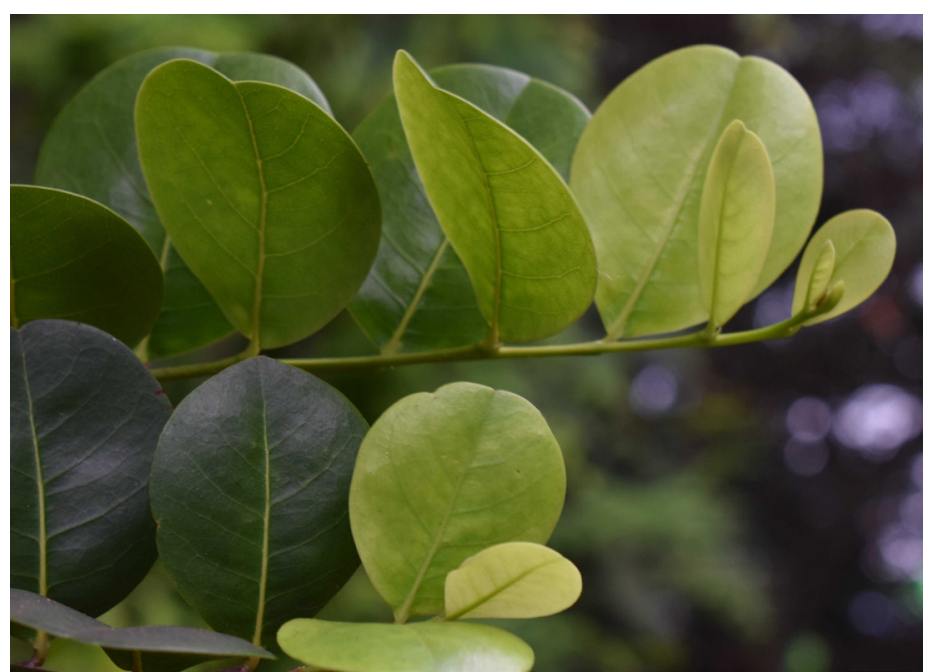

Figure 14. Simple, rounded, and rather leathery leaves alternately arranged and angled upward forming a $V$ shape.

Credits: Stephen H. Brown, UF/IFAS

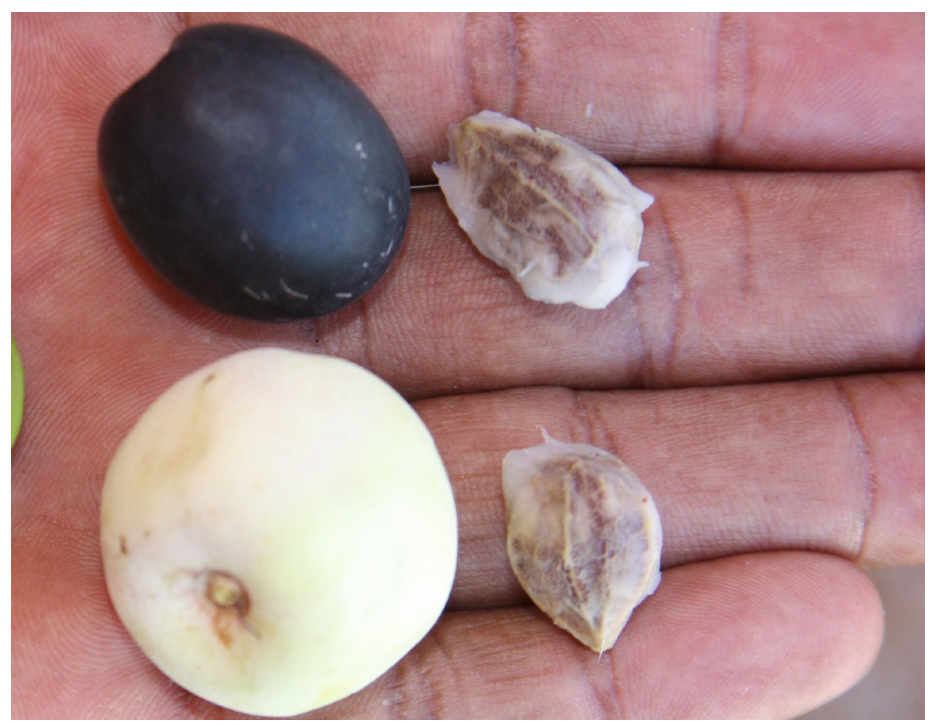

Figure 15. Single-seeded, round to oblong fruits with white to purple skin and sweet, white flesh.

Credits: Stephen H. Brown, UF/IFAS

\section{Growing Conditions}

Cocoplum may be grown in moderate to light shade or full sun. Both ecotypes and all cultivars can be cultivated on both coastal and inland sites. Soil tests done by Lee County Extension have found naturally occurring cocoplum growing in soil with a $\mathrm{pH}$ range of 6.6 to 8.4. Established plants have a high flooding tolerance, and many grow along fresh water canals and in soils seasonally inundated for several weeks by fresh water. However, newly installed plants are not as water-tolerant and may develop root rot in saturated soils. Minor leaf damage occurs at $32^{\circ} \mathrm{F}$ and severe stem and leaf injuries at $28^{\circ} \mathrm{F}$. 


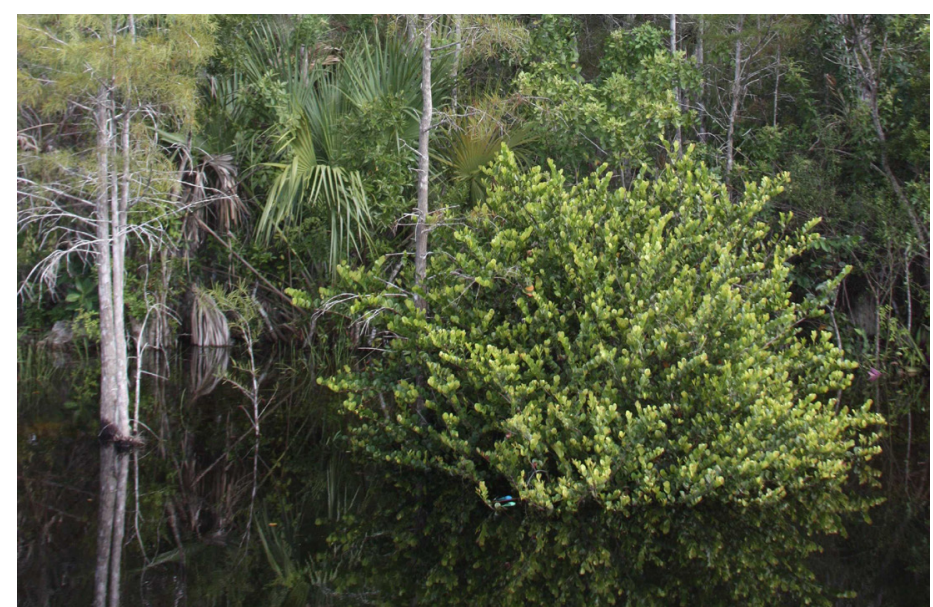

Figure 16. Cocoplum seasonally inundated by fresh water. Credits: Stephen H. Brown, UF/IFAS

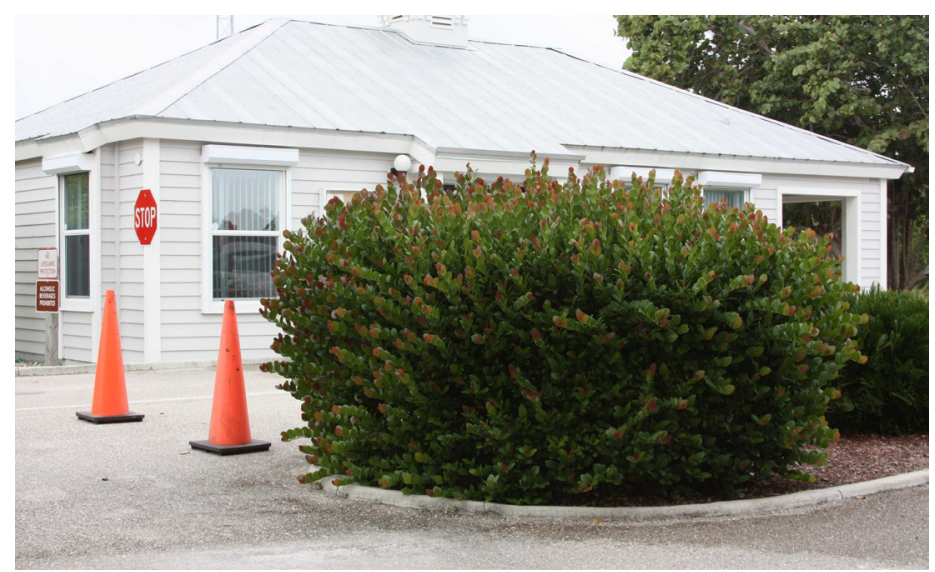

Figure 17. Cocoplum in high pH soil.

Credits: Stephen H. Brown, UF/IFAS

\section{Landscape Uses and Maintenance}

Cocoplum makes an excellent landscape plant and is widely cultivated in parts of Florida that are not prone to hard freezes. Plants not established are more susceptible to cold damage than older, established plants. In marginal areas, it is best to plant cocoplum from late March to September so that the plants are well-established before winter arrives. Those planted in February through May, the dry season, should have a reliable source of irrigation water to speed establishment and to assure their growth and survival. In severe dry conditions, and where a formal look is desired, established plants should be irrigated at least weekly to prevent dry and fallen leaves.

All cultivars may be used for screening and hedging. To create a hedge using the inland form, space plants 36 to 50 inches apart on center. The 'Red Tip' cultivar will take about 12 months to develop an acceptable hedge. Hedges should be pruned up to three times a year to keep them in shape. Hedges of the inland form are typically maintained at four to eight feet tall. Those of the coastal form are usually maintained at three to six feet tall.

The 'Horizontal' cultivar is favored for planting as a groundcover around houses, in commercial landscapes, and on roadway medians. It is especially useful where an unobstructed view of the waterfront is desired. Even when provided with regular irrigation for establishment, it may take a couple of years to become dense. Prune the shoots that are beginning to grow upright. This keeps the shrub low to the ground, encourages new tip growth, and provides a denser groundcover capable of reducing weed growth. With occasional pruning of upright shoots, 'Horizontal' groundcovers can be maintained at heights of 18 to 24 inches or taller if desired.

Bushy shrubs (mostly of the inland ecotypes) may be pruned into small, multi-trunked trees. Cocoplum's nutritional requirement is low. However, young plants grow faster with adequate fertilization. Once a plant reaches four or more feet tall in a hedge row of the inland ecotype, fertilization is rarely (if ever) needed.

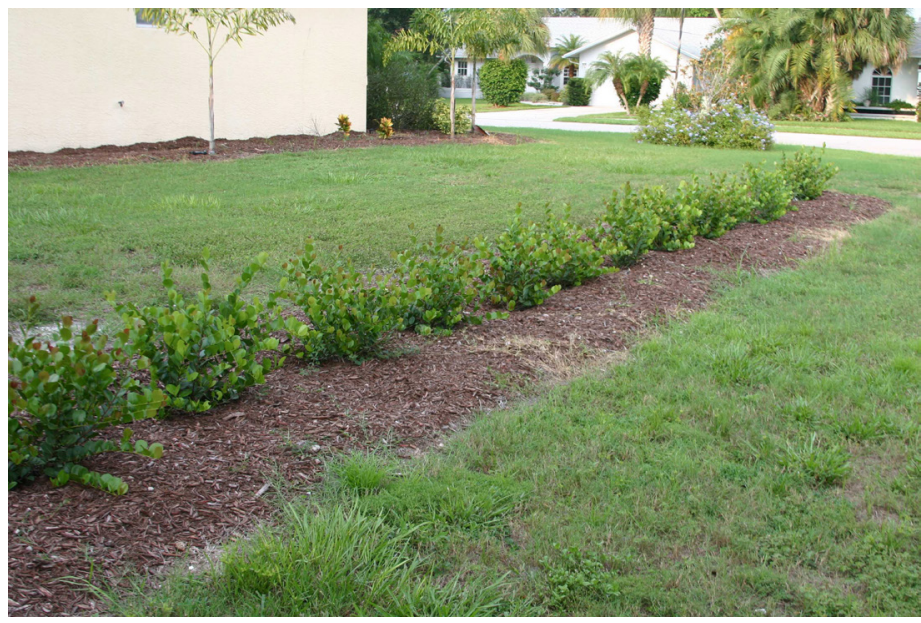

Figure 18. The start of a 'Red Tip' hedge.

Credits: Stephen H. Brown, UF/IFAS

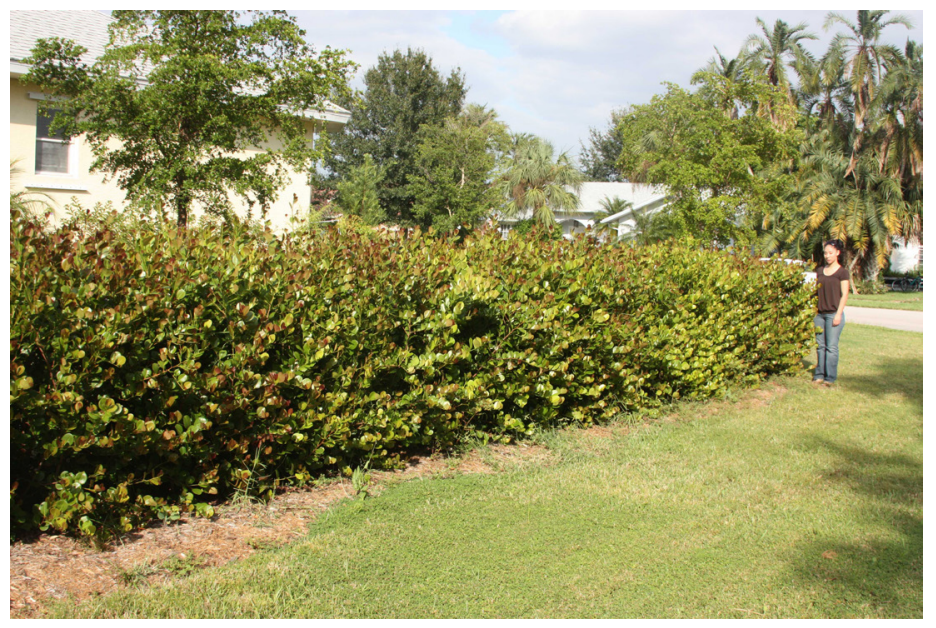

Figure 19. The same plants, 14 months later.

Credits: Stephen H. Brown, UF/IFAS 


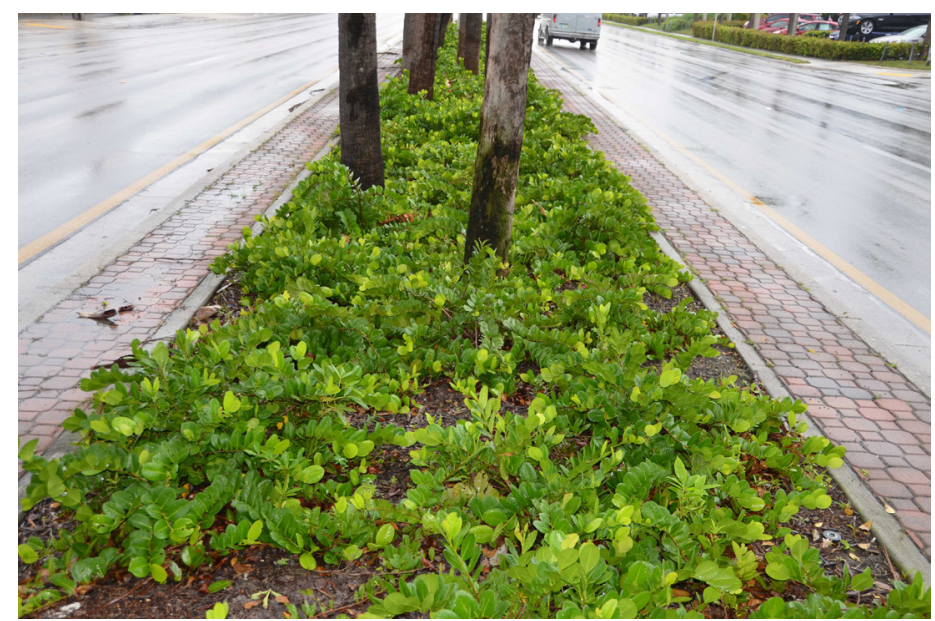

Figure 20. Recently planted 'Horizontal' cultivars in a 9-foot-wide roadway median.

Credits: Stephen H. Brown, UF/IFAS

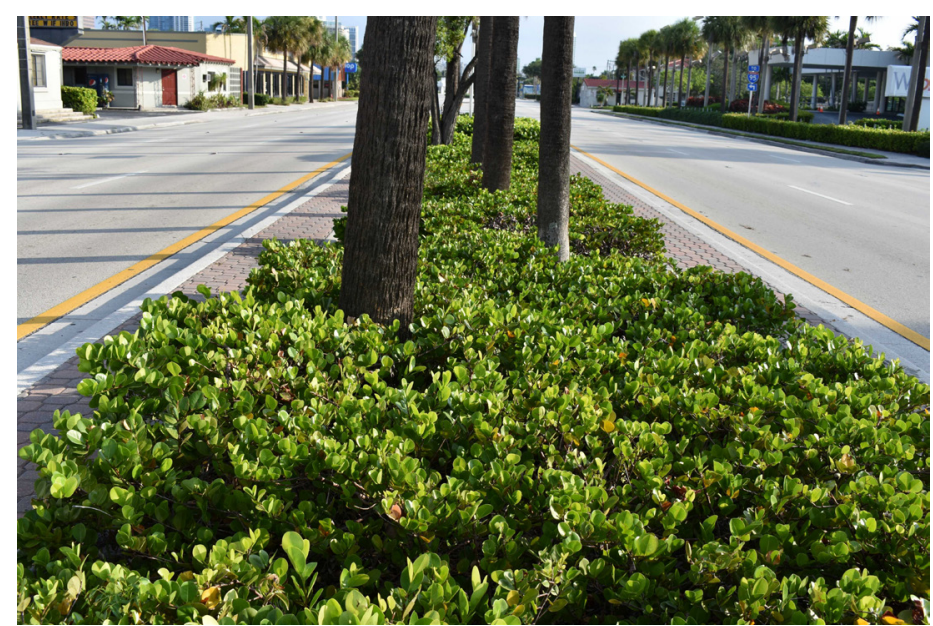

Figure 21. The same plants four years later and maintained at 20 inches tall.

Credits: Stephen H. Brown, UF/IFAS

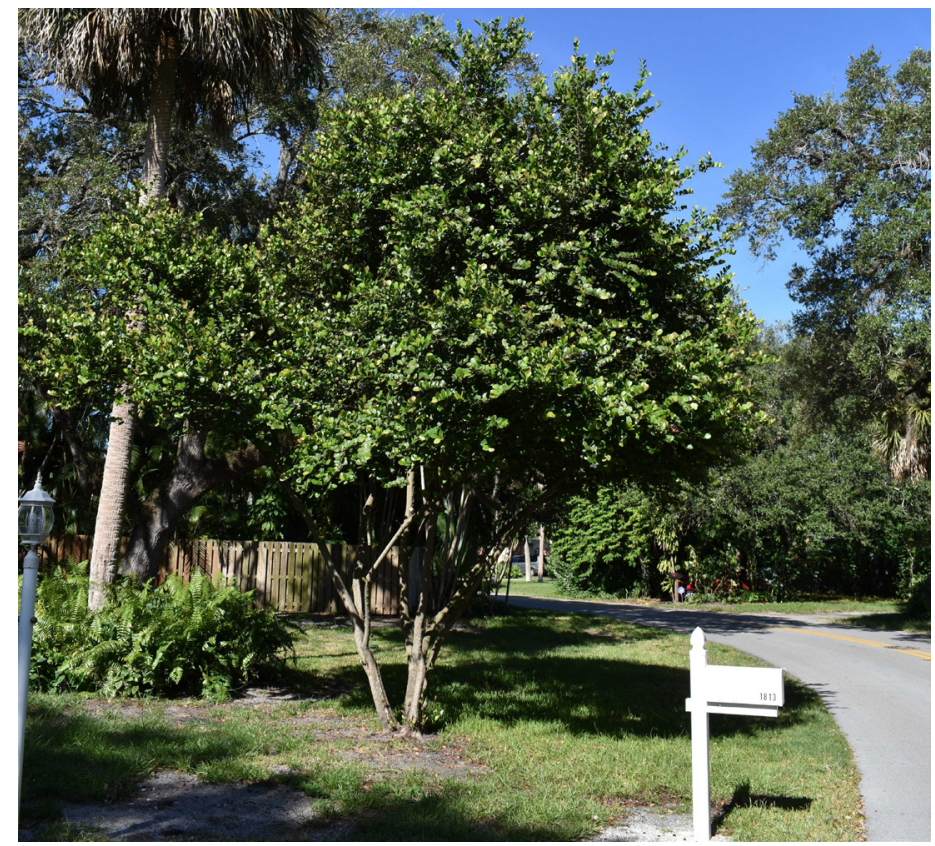

Figure 22. Small, multi-trunked 'Red Tip" tree about 15 feet tall. Credits: Stephen H. Brown, UF/IFAS

\section{Edibility}

Fresh fruit picked from plants are edible. Early immigrants to Florida discovered that the fruit's unique flavor, fleshy consistency, and thin skin make it excellent for making jams and jellies, and it is still used for this purpose today. The seeds inside the pit can be roasted and eaten for their almond-like flavor or crushed and added to the jelly. The fruit are readily consumed by gopher tortoises and other wildlife. Nectar from the flowers produces a dark-colored honey.

\section{Propagation}

Propagation of all cultivars can be done by seed, but more often are done by 4 - to 8 -inch-long terminal stem cuttings. 'Horizontal' should be propagated from a reliable source and only from stem cuttings to guarantee plants are true to type. Select the lowest running lateral stems for propagation. 'Red Tip' and 'Green Tip' cuttings should come from plants with purple and white fruits, respectively. Cuttings will root quicker if started in the spring from non-flowering and non-fruiting stems.

Gently remove the lower leaves from the stems and dip the exposed nodes in rooting hormone. Carefully place the treated nodes in a free-draining potting substrate. It is recommended that leaves on the cuttings above the substrate be retained. Commercially, new cuttings are started in full sun or shade of up to $70 \%$ and frequently mist to prevent the leaves from drying out. Cuttings under those conditions may take 3 to 6 months to root sufficiently before being removed from the mist beds and moved to areas of less shade, if necessary. At that point, plants may be transplanted into one-gallon containers and later into three-gallon containers. Plants kept in partial shade should be sun-hardened before sold. It may take a year or longer to obtain a good quality, commercial gallon-sized container plant. Many growers report substantial losses of cuttings before plants are ready for sale.

Gardeners can follow a similar procedure by starting cuttings in a shady location, in one-gallon containers, with frequent irrigation, before locating them to areas of increased sunlight.

Propagation from seed is done by removing the white pulp from the fruit and slightly burying the exposed endocarp in a free-draining substrate for germination. The substrate should be kept moist until roots are established. This method is generally not as successful and has a longer production time than using rooted cuttings. 


\section{Insects, Diseases, and Disorders}

Cocoplum is a sturdy landscape plant that, when planted in the right place, has few insect or disease problems.

Nevertheless, some problems may occur.

\section{Insects}

Lobate lac scales (Paratachdina pseudolobata) and the accompanying sooty mold deposits on leaves and stem are sometime seen. These insects infest more than 150 host plants, including wax myrtle (Morella cerifera), wild coffee (Psychotria nervosa), and black-olive (Terminalia buceras).

The little leaf notcher (Artipus floridanus) makes shallow notches along the leaf blades sometimes so uniform that they appear to be natural leaf serration rather than feeding damage. The Sri Lanka weevil (Myllocerus undecimpustulatus undatus) chews both shallow and deep notches along the leaf margins. The feeding pattern is very noticeable.

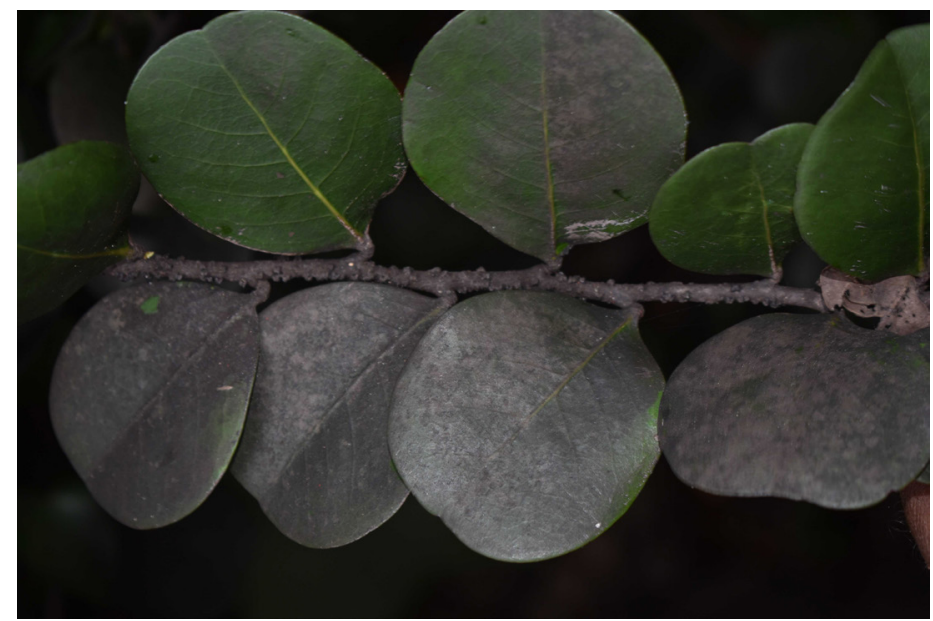

Figure 23. Residual lobate lac scales and accompanying sooty mold. Credits: Stephen H. Brown, UF/IFAS

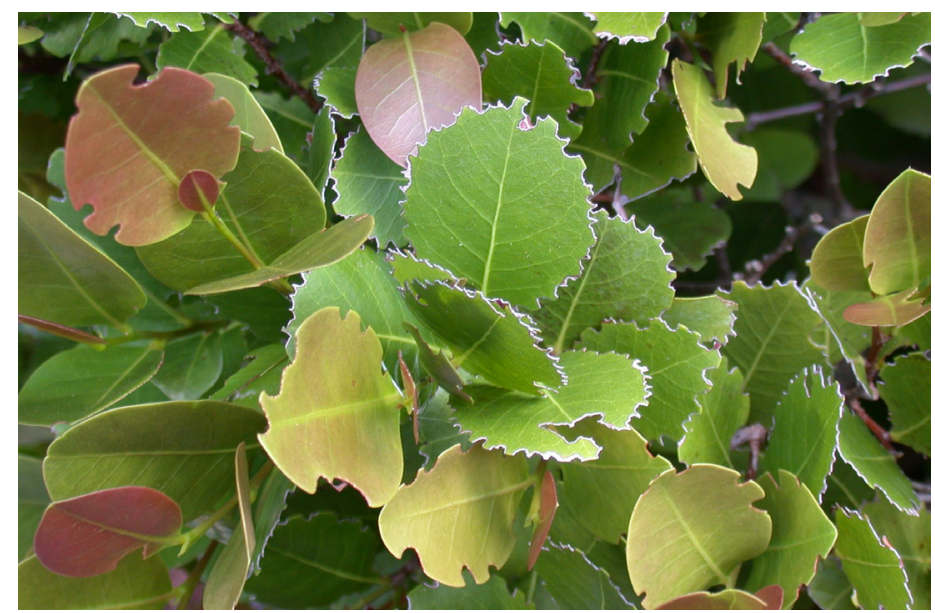

Figure 24. Damage to cocoplum caused by little leaf notchers. Credits: Douglas Caldwell, UF/IFAS

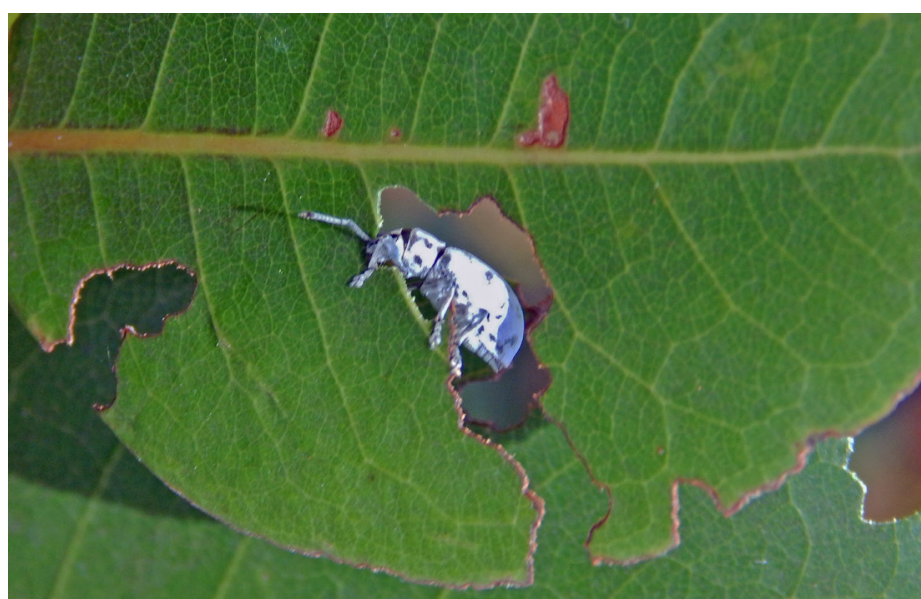

Figure 25. Sri Lanka weevil feeding on cocoplum. Credits: Douglas Caldwell, UF/IFAS

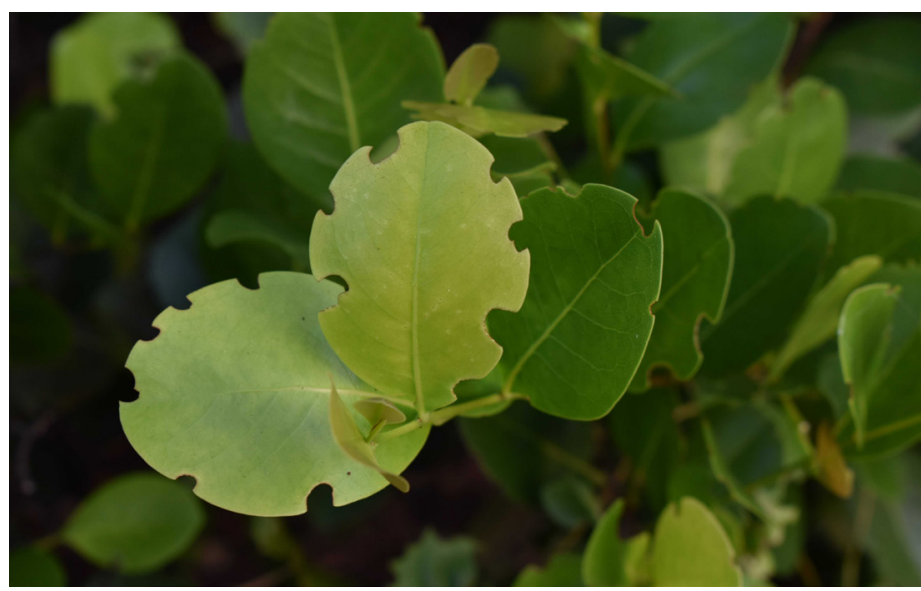

Figure 26. Damage to cocoplum caused by Sri Lanka weevil. Credits: Stephen H. Brown, UF/IFAS

\section{Diseases}

Algal leaf spot (Cephaleuros virescens) is a parasitic green alga that occurs primarily in southeastern states, where it may be a common sight on certain plants. The disease first appears as raised blotches or spots on the leaf surface. The blemishes are round, green to gray, and somewhat fuzzy or velvety. The green spots will turn reddish-brown with age, and, during periods of high humidity, may be confused for a rust disease. Plant tissues often deteriorate and die underneath the spots, which frequently causes partial defoliation. On some hosts, the alga can cause tip dieback due to the production of a phytotoxin that kills the plant tissue.

The first noticeable symptoms of Botryosphaeria (Botryosphaeria sp.) canker and blight are yellow and premature leaf drop. Cankers eventually split and girdle stems, resulting in persistent dead leaves. Expanding cankers may kill all parts of the plants above the affected areas. One or more plants in a hedge row may be affected. Cankers are often more pronounced where wounds occur, or on plants that have 
been water-stressed. If infection happens in the crown, the whole plant may die.

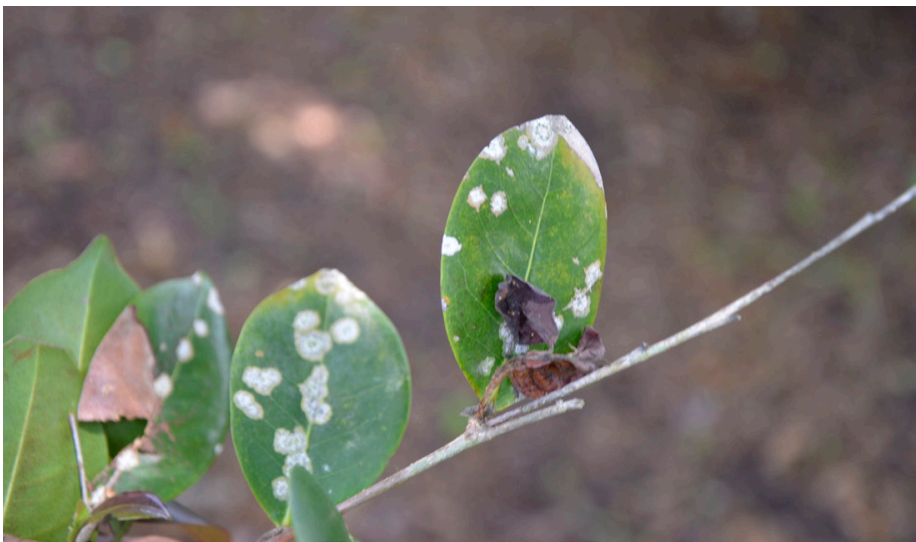

Figure 27. Algal leaf spot and stem dieback caused by Cephaleuros virescens.

Credits: Stephen H. Brown, UF/IFAS

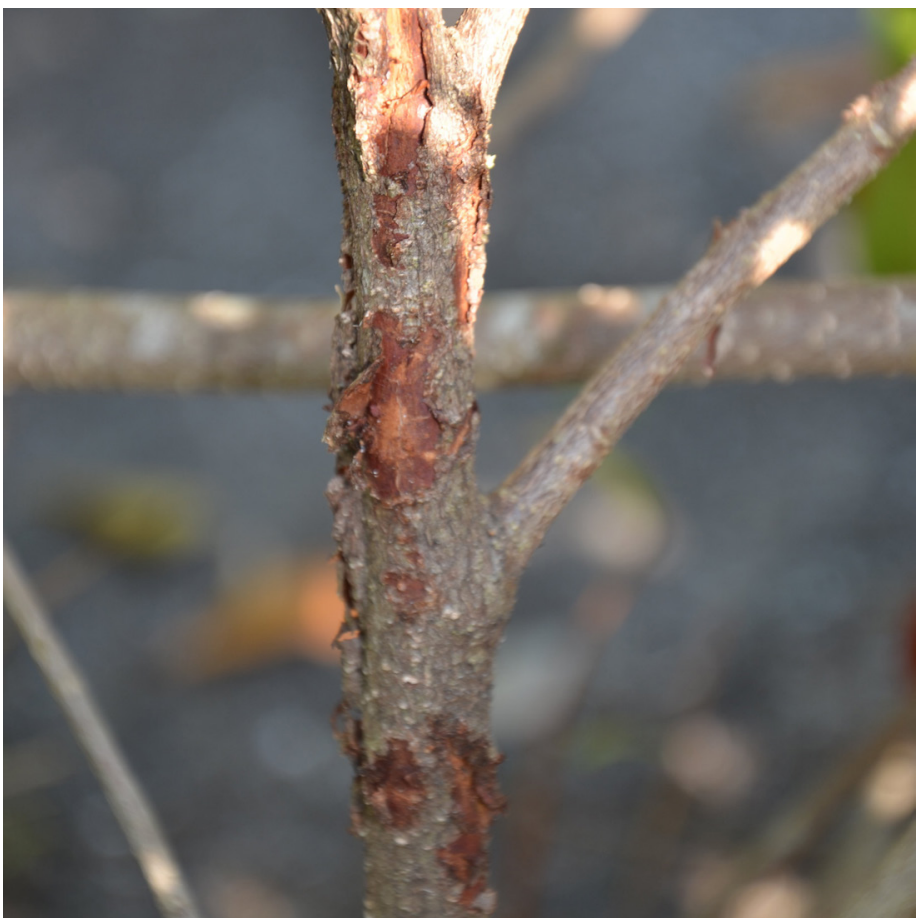

Figure 28. Botryosphaeria canker on cocoplum.

Credits: Stephen H. Brown, UF/IFAS

\section{Disorders}

Plant disorders are caused by abiotic (non-living) factors (such as environmental stress), including over-irrigation, drought, or excessive pruning. Cocoplum and other plants may slowly decline when planted after being pot-bound for several years. The decline is especially pronounced when a plant is heavily mulched and exposed to prolonged soil moisture. Decline symptoms are similar to those of Botryosphaeria canker and blight.

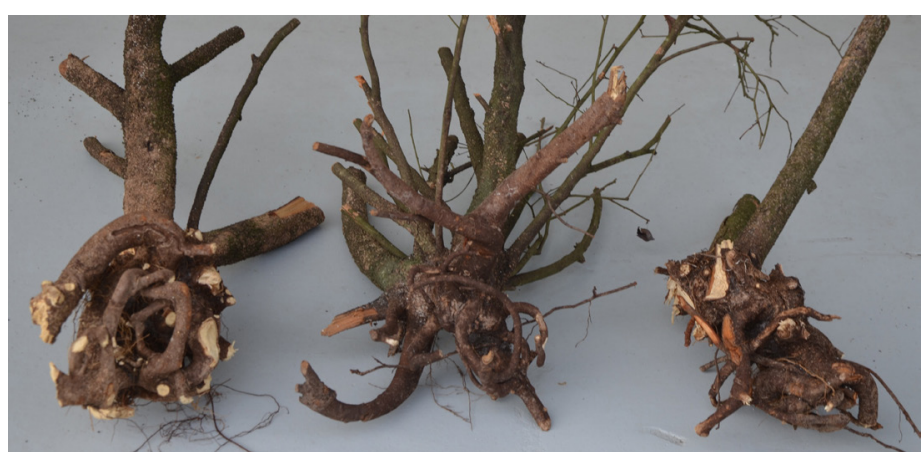

Figure 29. Circling roots of pot-bound cocoplums.

Credits: Stephen H. Brown, UF/IFAS

\section{References}

Broschat, T.K. and A.W. Meerow. 2001. Reference Guide to Florida Landscape Plants. Hollywood, Florida: Betrock Information System, Inc.

Gann, G.D., M.E. Adbo, J.W. Gann, G.D. Gann Sr., S.W. Woodmansee, K.A. Bradley, E. Grahl, and K.N. Hines. 2016. "Cocoplum: Chrysobalanus icaco." http://www.regionalconservation.org/beta/nfyn/plantdetail.asp?tx=Chryicac

Prance, G.T. 1970. “The Genera of Chrysobalanaceae in the Southeastern United States." Journal of the Arnold Arboretum 51(4): 521-528.

Prance, G.T. 1972. Flora Neotropica Monograph No. 9: Chrysobalanaceae. New York: Hafner Publishing Company, Inc.

Tomlinson, P.B. 1986. The Biology of Trees Native to Tropical Florida. Massachusetts: Harvard University Printing Office

Whetstone, R.D. and C.F. Nixon. 2016. "Chrysobalanus." In Flora of North America, Editorial Committee eds. 1993+. Flora of North America North of Mexico 20+ vols. Vol. 12, p. 366. New York and Oxford.

Workman, R.W. 1980. Growing Native: Native plants for landscape use in Coastal South Florida. Sanibel, Florida: The Sanibel-Captiva Conservation Foundation, Inc. 